\title{
EXPANDING THE CONCEPT OF PEOPLE AFFECTED BY HPP: JIRAU AND PENHA VILLAGE SETTLEMENTS - RONDÔNIA
}

\author{
Artur de Souza Moret \\ Clara Miranda Santos \\ Rafael Ademir Oliveira de Andrade \\ Berenice Perpétua Simão \\ Jeferson Cardoso da Silva \\ Clarides Henrich de Barba
}

${ }^{I}$ Universidade Federal de Rondônia, Porto Velho, RO, Brasil.

"I Instituto Federal de Rondônia, Porto Velho, RO, Brasil.

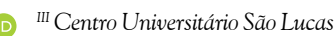
Porto Velho, Porto Velho, RO, Brasil.

D IV Universidade Federal de Rondônia, Porto Velho, RO, Brasil.

${ }^{V}$ Instituto Federal de Rondônia, Porto Velho, RO, Brasil.

${ }^{V}$ Universidade Federal de Rondônia, Porto Velho, RO, Brasil.

\begin{abstract}
This work seeks to discuss the conception of affected and the reconfiguration of the territory and social lives with the observation and analysis of two communities not considered affected by the Jirau HPP: that of the small Village Jirau and Village of the Penha. The research is characterized as theoretical-descriptive, based on the issues related to the territory of occurrence of impacts of the construction and operation of hydroelectric plants, and fieldwork was performed with non-participant observation, the data were compiled from the perception of the researchers and allow us to conclude that the damage of the construction of the HPP, in these communities, put them in a condition of being affected, the impact happens in the territory as a result of the influence and confluence of the networks of life lived, comprising the river and what relates it, the connecting roads, the networks of housing.
\end{abstract}

Keywords: Settlements. Affected. Hydroelectric plants. Madeira Complex.

São Paulo. Vol. 24, 2021

Original Article

DOI: http://dx.doi.org/10.1590/1809-4422asoc20200132r2vu2021L3DAO 


\section{Introduction}

Since the 1950s, in the name of development, major economic projects that seek energy sources through hydroelectricity have been appropriating territories already occupied to the detriment of local populations. Entire communities are displaced, reoriented, and families suffer material losses, in addition to breaking irreparable emotional ties (BORTOLETO, 2001).

The large enterprises, that seek to obtain profit under the exploratory logic of natural resources, benefit the economy by eliminating the reality of the populations that have material and immaterial links with the lived Territory, and the attention paid to those populations is very superficial (SILVA; SILVA, 2011). This Territory is composed of experiences and life, in which economic, social and environmental relations are completed with symbolic issues and cultures interconnected to the (living) space that is the River and its functioning, its banks, its fishes, its flooding and its ebb. The impacts related to hydroelectric projects produce radical transformations in the Territory; however, if the reflection that the most negatively impacted portion is the one that belongs to the Lower Circuit of the Economy (MORET, 2018) is included, this study becomes even more complex (MORET; SILVA, 2010).

The so-called "development project" for these large enterprises is the object of study by several groups that seek to understand and measure the size of the environmental, social and subjective transformations generated by the interventions carried out and motivated by them, the groups. According to the studies by Araújo and Moret (2016), Ribeiro and Moret (2014), and Ribeiro, Andrade and Moret (2015), the socioenvironmental impacts cause negative reflexes and take on giant dimensions for the citizens who inhabit the places of the enterprises, since they are compulsorily displaced and the ways of life in the new places are different from the original ones. Sassen Saskia $(2016$, p.19) refers to this process as compulsory displacements as expulsions, and states that "... today, the oppressed, for the most part, have been expelled and survive a great distance from their oppressors. Furthermore, the "oppressor" is increasingly a complex system that combines people, networks and machines, without having a visible center."

The new locations of the resettled people are usually far from rivers, or when they are close, they are not allowed to fish anywhere, there is an interruption in the use of the river and, even, loss of biodiversity culminating in a decrease in the quantity and diversity of fish. Cavalcante and Santos (2012) explain that territorial (re)structuring, which the enterprise promotes in the place of its implantations, allows to show, in the area, tensions in face of the different interests about the use of the territory and its resources.

The discussion on environmental and social impacts - the result of the implantation of hydroelectric power plants (HPP) is growing and has an important role for Science. However, there is still an important gap to be overcome, which is the definition and determination of the scope of these impacts, above all, regarding the quantity and who are the ones who suffer the impacts of the HPPs.

The companies clearly define who will be affected: those who live on the edge of the barred river and also those who live in areas close to the construction sites. This defini- 
tion is conflicting for the various movements organized by those who suffer the impacts, such as the Movement of People Affected by Dams (MAB), and for the State Public Prosecutor's Office (MPE) and the Federal Prosecutor's Office (MPF). This definition, which emerges from the water/patrimonialist strands, is flawed, as the impacts are felt by all those who suffer the effects and, therefore, excludes many of those affected who are in Territories that have several influences, close or not, to the river barred.

The article intends to discuss the concept of affected people from the reconfiguration of the Territory that is influenced by Rio through the study of two communities not considered affected by the Jirau HPP: the community of the small village Jirau and the Penha Village. In this way, it will configure the concept of reached by hydroelectric enterprises.

\section{PERSPECTIVES ON TERRITORY AND TERRITORIAL SPACE}

Santos (1999, p. 8) understands that the territory goes beyond the merely geographical and spatial issue, in which it is thought as the "place where all actions, all passions, all powers, all strengths, all weaknesses lead to, i.e., where the history of man is fully realized from the manifestations of his existence".

The territory is not only the union of natural resources in a defined geographical space, it is necessary to be conceived as the place where the characteristics of a people are formed and shaped. One must consider it as a form of identity, in order to feel part of that ground and attached to it. In it, the reason for being is guided, it can be modified according to the needs, it is the place where roots are established, social and spiritual experiences and experiences are exchanged (CAVALCANTE; SANTOS, 2012).

It is of fundamental importance to highlight the points of tension in the context of struggles for Territories across the planet, with an emphasis on compulsory displacements due to the construction of Hydroelectric Power Plants, mineral extraction and biofuels that, according to Escobar (2014, p. 77)

can be seen as a real war against the relational worlds and an additional attempt to dismantle the collective. Within this complex situation, the fights for the territories become fights for the defense of the many worlds that inhabit the planet.

In the territory, there is a perspective of survival, life project and future, which, according to Escobar (2014, p. 88), would be the "collective space, composed of all the necessary and indispensable place where men and women, young people and adults, create and recreate their lives".

From this conception of Territory, it is possible to understand the complexity of the dimensions and relationships that interconnect forming an invisible web of individual and collective contacts and, when these are destroyed, a rupture is created with the symbolic links of social space. Thus, regarding the circumscription of territorial space for those affected, there is in no case any prior definition of affected or influential territo- 
rial circumscriptions, with studies and dialogue with interested populations identifying impacts and those that are negatively affected. The closest definition of territory, with all possible limitations, was produced by Eletrobrás suggesting that socio-environmental studies should have a spatial scope that allows the adoption of a broader concept and with analytical cuts, among them, "the representative areas of the spatialization of affected socioeconomic and cultural flows and relations" (BRASIL, MINFRA, 1990, p. 28).

The territorial space that surrounds the undertakings refers to the context of displacement of large hydroelectric projects that start to break the ties already defined by the territories in their way of life and existence, which forces those affected to move from one area to another - this it means leaving behind their homes, their social, and economic way of life (JACOBI, 2003).

In this context, the space has different perspectives that involve the materiality of the world and society in which human beings are built through their struggle for social relations and perceptions in which they find themselves. These built relationships depend on cultural collections and physical survival that involves facts related to social practices. In view of this understanding, we highlight the structure of the space that corresponds to the conceptions of material practices with which people live in their daily lives, in the same way that Arturo Escobar (2014) describes the relationship of the riverside and his family with the rivers, with their banks and their differences in understanding and territorial relationship, it is possible to extend to understand the spaces occupied by those affected in this study.

The Madeira River Hydroelectric Plants show the construction of energy sources in which social issues were neglected, in addition to the neglect of public policy actions involving the transformation of identities resulting from changes in rural production modes, natural extraction that caused a rupture in social cohesion in the face of impacts.

Studies related to environmental and social impacts have shown that the hydroelectric dams on the Madeira River imposed high complexity impacts, and as such had the need to carry out new studies, which was not done during the elaboration of the Basic Project related to the projects, there was an understanding on the part of the government of the need to implement the enterprise. Because of this gap, the character of sustainability in the face of environmental, social and economic impacts for the municipality of Porto Velho, has been relegated to the background (GARZON, 2009; MORET; SILVA, 2010).

Social systems have networks of intrinsic and connected meanings that, when suffering external influences, are readjusted, based on a more rigid cultural nucleus (GEERTZ, 2008) and, in the context of HPPs on the Madeira River, these impacts were varied and reported in several documents, among which we highlight: the non-increase in the population's service infrastructure during the demographic explosion during the construction period, the increase in violence in the construction regions (44\% more homicides and 208\% more rapes) between 2008 and 2010 (MARQUES, 2017), compulsory displacements to places that are difficult to maintain their ways of living (for example, settlements distant from river beds) or already occupied by other communities of extractivists (DHESCA, 2011). All these impacts at different spatial scales go directly back to 
the need to transform ways of living and identities so that the subjects can continue to live from a preserved identity memory - being riverside despite being in an urban setting, being a fisherman even though they are far from the river, among other possibilities and narratives.

Thus, impacts analyzed in relation to the large dams show the threats to the economic survival and the way of life of the peasants who had a specific culture and different from the industrialization process, which is evidenced with the advance of the capitalist process to the locality. In this sense, the reality of the impacted communities is against the theoretical and practical issues related to the process of economic and sustainable development in the face of the relationships between man, society and nature (JACOBI, 2003).

It is observed, therefore, that those affected cannot be limited to the flooding area of Jirau HPP, but to the entire Territory of influence, encompassing: a) the social perspective - relationships between people, neighborhood relations, biome, cults, cultures, cosmologies and ethnicities; b) territorial - forests, rivers, lakes, relations with society's space for good living, historical and political possession of spaces; c) economic - survival, use of economic space; d) political - organizational communion, models of economic, social and environmental management; and finally, e) ethics - balance and harmony with the environment (JACOBI, 2003).

\section{CURRENT CONCEPT OF PEOPLE AFFECTED IN THE CONTEXT OF HYDROELECTRIC PLANTS}

Citizens impacted by hydroelectric projects are called affected, whose concept varies according to the political and cultural context. According to Vainer (2008), the discussions about the affected can be analyzed in two aspects: the territorial-patrimonialist, which the entrepreneur's action is determined by the acquisition of the domain (land ownership), in which the population is an obstacle that it needs to be removed for the work to become viable; and the water aspect, which is reached by flooding. In this regard, Vainer (2008, p. 7), highlights:

Now, on many occasions it has become evident that municipalities without any flooded area may suffer more severely the consequences of the implantation of a hydroelectric plant than municipalities with areas taken by the reservoir waters, but this is not contemplated by the legislation, due to the water concept.

To understand what and how it is to be in the condition of being reached, it is necessary to extrapolate the strictly pecuniary or material dimensions. The enterprise is considered by Vainer (2008) to trigger irreversible social changes and imposed by the transformation process without following a natural flow of changes that would occur if there was no intervention.

The understanding reached by hydroelectric projects is related to the people who must be displaced, it is connected to the direct space of interference (construction site, 
transmission lines) or to the flooding of the HPP. It is understood, therefore, that the impact is greater than just a matter of direct geographic space of interference, because the influence is greater than just in the flooded space. It also occurs in the immaterial, in the conditions of life lived and in survival. There is a widening of the HPP's influence, which is not strictly linked to the geographic space, but there is interference in a Territory of lived life related to the networks of influence and confluence of life lived in the surroundings of Rio.

The definition of reached is centered exactly on the conflict between what is practiced by the entrepreneurs and the widening of the influence and confluence of the lived life. Thus, being reached constitutes the field of dispute between the various actors: entrepreneurs, organized movements of impacted, Public Ministry and justice, licensing agencies (SILVA; SILVA, 2011), and this field of dispute is not limited to recognition; as such, it covers the space of life, survival, relationships, influence and confluence of lived life.

Although the term appears in technical documents and refers to economic and financial dimensions, the notion is neither merely technical nor strictly economic. It is a concept in dispute, the notion of affected person actually concerns recognition, i.e., the legitimation of rights and their holders. In other words, establishing that a particular social group, family or individual is, or has been, reached by a particular enterprise means recognizing as legitimate - and, in some cases, as legal - their right to some kind of reimbursement or indemnity, rehabilitation or reparation not pecuniary. This explains why the scope of the concept is itself the object of a dispute and that it triggers a conflict.

To address the discussion about the concept of affected, it is necessary to understand that the recognition and legitimation of rights is being discussed, and it seems to be a consensus among multilateral agencies that the notion of affected refers to the set of economic and social processes triggered by the enterprise and that may have perverse effects on the population's means and ways of life (SILVA; SILVA, 2011).

It appears that the effects produced by the HPP are interferences in the lives of those who were displaced (assumed by the companies as impacted) and also in a portion that was neglected by the HPP and had their lives altered because they were in the surroundings and under the direct influence of the construction of the enterprise. The studies by Owusu et al. (2017), Siciliano et al. (2015) reveal the damage caused downstream of the dams, that is, in regions that are not understood as the area of impact of the plants, in addition to finding that the EIA reports do not include specific social measures on the different impacts that affect the local populations. Tajziehchi et al. (2012, p. 1841) show that the negative impacts in the construction phase are much greater $(66.2 \%)$ than the positive ones $(33.7 \%)$.

\section{CONFLICTS IN THE AMAZON: RESULT OF A HISTORICAL OCCUPATION}

The discussion on conflicts in the Amazon can be made by several theoretical ap- 
proaches, however the disciplines that have invested more in the theme are Anthropology, Sociology and the theory of regional development in an interdisciplinary way. Discussions on development, growth and sustainability, from the perspective of each science, were reinforced between the 1960s and 1970s of the 20th century with the analyses of the Club of Rome and the 1st Conference of the United Nations Organization on the Human Environment, also called the Stockholm Conference, held in 1972.

In turn, in 1987, the World Commission on Environment and Development in 1987 of the United Nations Environment Program - UNEP, constituted the "Brundtland Report", also known as "Our Common Future", which presented significant results for the terms of sustainable development and sustainability in the environmental context. From it, discussions were created on three main axes: the environmental, the social and the economic, thus allowing the formulation of public policies of a global scope involving the preservation and conservation of the entire planet (WORLD COMMISSION ON THE ENVIRONMENT AND DEVELOPMENT, 1991).

These events marked the insertion of analyzes of socio-environmental conflicts in the discourse of major national and international agents, such as the World Bank. This does not mean that, in a parallel and continuous way, resistant agents have not discussed the issue of environmental and human relations in the Amazon and other spaces, such as, for example, the indigenous works that preceded the 1988 Constitution.

From these discussions, coupled with major catastrophes, the need to think about a new posture in the economy that combines the environmental issue with sustainability becomes essential. Thinking about new ways of exploiting human resources in a more balanced way, we think about sustainable development that historically represents the attempt to mediate humanity with fundamental questions for its existence. Thus, we can think about conflicts - with spatial delimitation of the Amazon as disruptions between the interests of capital expansion and the sustainability needs of individuals located in the region (LIBISZWESKI, 1992).

Libiszweski (1992) considers that the conflict is caused by the scarcity of the product, leading individuals from one territory to occupy another due to the lower rate of regeneration or total scarcity of a certain resource, which would explain, in a particular way, the expansion of livestock culture and invasions of conservation units and indigenous lands in the Amazon by private and state agents.

Becker (2001) thus relates socio-environmental conflicts to environmental or economic imbalances, such as migrations from northeasterners/southerners to Rondônia in the first decades of the twentieth century to seek a scarce resource, whether it be land, water, hunting, among others. From these migratory movements we have anthropic actions that cause varied and systemic impacts on the Amazonian territory.

Conflicts occur when, in dispute over environmental and social resources and their uses, groups clash with strategies to achieve hegemony in the use of these resources - a use that can vary according to the cultural notions of the nature/culture relationship and economic priorities. In the Amazon, conflicts are expressed between collective interests versus private interests, use of public spaces by private agents and appropriation of public 
spaces by agents (BECKER, 2001), which are expressed through illegal deforestation, invasion of protected and indigenous areas, mineral extraction illegal.

These conflicts can be clear or subjective. Some have little visualization by society (invasion of protected and indigenous areas, illegal mineral extraction) and tend not to be associated with environmental degradation - such as, for example, endogenous movements in defense of large hydroelectric plants, which relate the enterprise to development and not they know, or wish, to consciously measure the impacts and conflicts arising from these actions.

\section{METHODOLOGICAL PROCEDURES FOR RESEARCH}

The research is characterized as theoretical-descriptive, based on issues related to the territory where the construction and operation impacts of hydroelectric dams occur, showing the geographical spaces of direct intervention composed of flooding, the construction site and the transmission line. It was held in a space different from that recommended by the HPP as directly impacted, producing the analytical construction that the impacted by the Plants belong to a Territory that is the result of the networks of confluence and influence of the life lived based in Rio and its surroundings.

The object of study was the construct of impacted by the hydroelectric dams of Madeira River, made up of people and spaces that suffered direct and indirect impacts from the Plants.

The concepts of conflict were used as a theoretical reference according to the studies of Libiszweski (1992) on affected people, the definitions of Vainer (2008), the Report of the World Commission on Dams (2000) and the understanding of territories according to the understandings de Santos (1999) and Escobar (2014).

The method applied in the research was proposed by Libault (1971) organized in four stages: 1 . Compilatory - data collection phase, for compiling and collecting data through interviews; 2 . Correlative - phase of data correlation, interpretation and groupings of the collected data; 3 . Semantics - screening of important points to be analyzed that meet the research objectives; 4 . Normative - formatting a model for data analysis. In the model for data analysis, the Risks and Vulnerability proposed by Cardona, (2001) and Wisner et. al (2003) was used.

The analyzes were built from theoretical and exploratory studies regarding the analytical construction, evidenced by the guiding question regarding "what is the territory where the construction and operation of hydroelectric dams are impacted?". The question reflects the assumptions, which is the Semantic phase, that the impacted are not just those limited to the geographic space of direct intervention composed of flooding, the construction site and the transmission line.

The exploratory questions were also built from the definitions of the theoretical concepts of this conflict research (territory versus affected) and Risks and Vulnerability, which is the Normative phase, forming descriptors that enabled analytical understanding, and the descriptors were analytically compared in the two communities. allowed to 
compose the definition of what is a hydroelectric dam's influence territory.

The data prospecting study, which is the compilation phase, was carried out in two communities called Jirau and Penha Village, which are in the vicinity of Jirau HPP and which had no indemnity or other compensation from the hydroelectric plants because they were not in geographic interventions defined in the electricity sector, which is the Correlative phase. The data collection was part of the post-doctoral research entitled "Studies of social, environmental and economic impacts in a settlement in Rondônia: the construction of HPP and intervention in the lower circuit of the economy" by Professor Artur de Souza Moret, with a survey of data, from semi-structured interviews, in three plants: Jirau-RO HPP, in the Nova Mutum Paraná Settlement (07 interviews), Jirau Village and Penha Village (54 interviews). At Lajeado-TO HPP, (11 interviews) in Block 604 North. At Chixoy HPP - Rabinal Municipality in Guatemala (15 interviews) in the Chitomax Communities, Narango, Pacux.

In the prospecting of data, the semi-structured questionnaire tool was used, applied to 54 (fifty-four) participants from the Vila Jirau and Vila da Penha settlements and local observation, in a random sample of interviewees who were willing to answer the questions of the reasons, when and how they arrived or are in the community.

Figure 1 - Study location

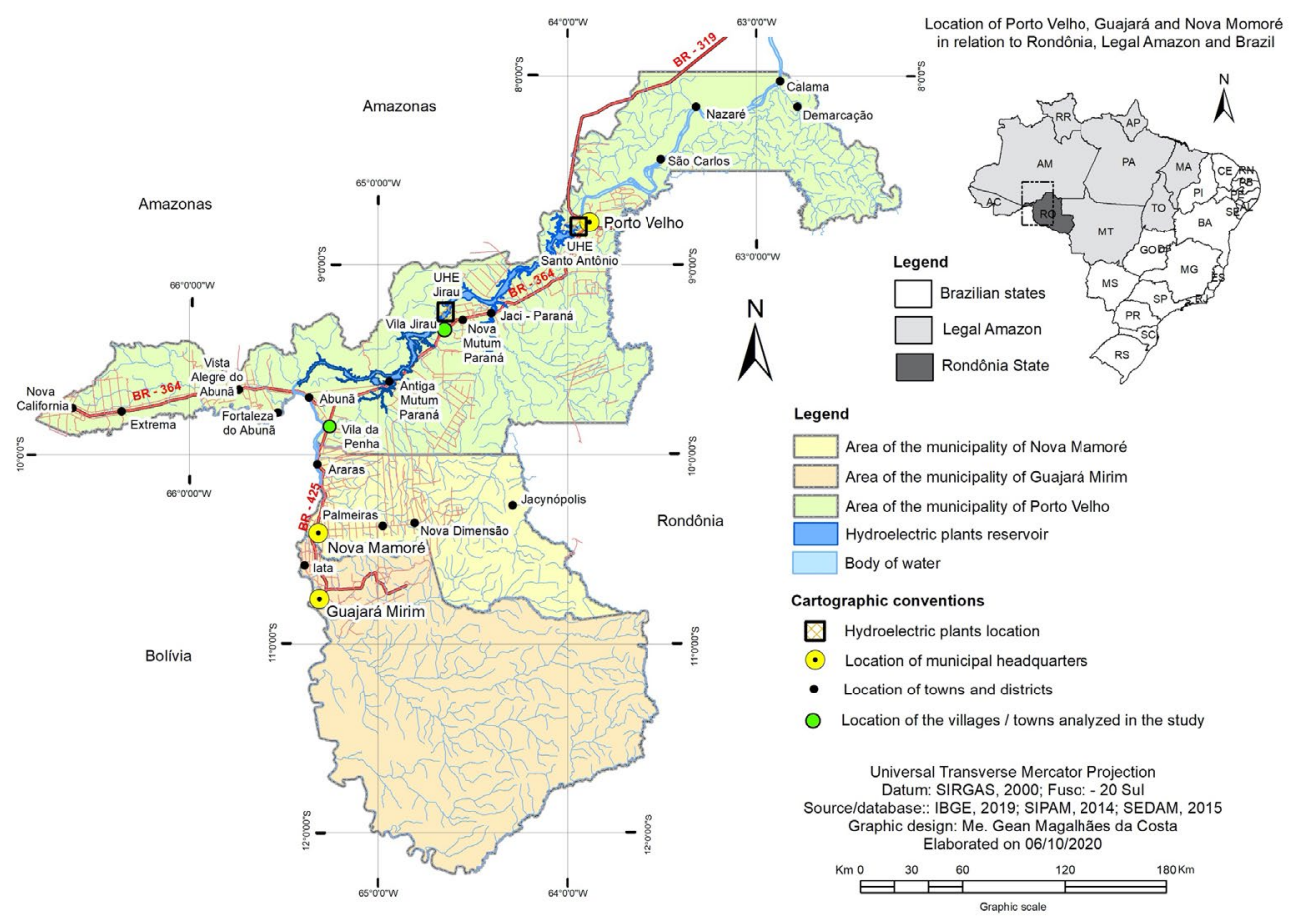

Source: The authors, 2021. 
Jirau Village is a community that occupies the two banks of the BR 364 and originated due to the creation of one of the stops of the railway station of the Madeira-Mamoré Railway, inaugurated in 1912 and deactivated in 1972. With the railway deactivated, the location was maintained as a stop for people and various land transports that travel between Porto Velho and Rio Branco (AC), as well as to reach Guajará Mirim and, consequently, the Brazil-Bolivia border. This is one of the closest communities to the Jirau HPP.

Penha Village is located on the margins of BR 425 and the oldest residents say that about 10 years ago a man opened a small shop and people gradually settled in and called the location of Penha Village - due to an old road that connects the District of Abunã (also an EFMM railway station), to BR 425. Small landowners, small farms or farms were breaking up their properties into small plots and selling them to new residents, thus the community became a favorable commercial point for small farmers in the surroundings who also concentrated the collection and distribution of milk production there - thus declared the residents of Penha Village during the interviews for this study.

The distance between Penha and Abunã is $16.42 \mathrm{~km}$, along the Velha da Penha road, different from the distance between the two locations on BR 425, towards the road. $364(16.66 \mathrm{~km})$ to Abunã $(28.13 \mathrm{~km})$ totaling $44.79 \mathrm{~km}$. It was the BR 425 that served as a reference for locomotion between Abunã and Penha Village mainly because it also accessed the Garimpo da Penha.

\section{TERRITORY CONFIGURATION IN COMMUNITIES AFFECTED BY JIRAU HPP: RESULTS AND DISCUSSIONS}

\subsection{Jirau Village and the influence of HPPs}

After the construction of the Jirau hydroelectric plant, the community on the banks of the Jirau River became a shelter for families and people due to several factors: a) easy access via BR 364; b) characteristics of a rural and riverside community and, therefore, receives immigrants from other similar areas; $\mathrm{c}$ ) the location closest to the hydroelectric plant after the lake flooded the Mutum Paraná community. Therefore, today Jirau replaces bus stops and other activities necessary for those in transit on BR 364 - previously carried out in Mutum Paraná. But it was the search for work and employment that most moved the migration from Jirau, motivated by the construction of the hydroelectric plant.

Therefore, our survey recorded an economic immigration that grew $80 \%$ in the last five years, with $65.4 \%$ of people of economically active age, under 50 years old. The records also show that $62 \%$ of the people who came to Jirau are from the state of Rondônia, came in search of work, as they were in places where work, employment and remuneration were bad. Part of these people (24\%) stated that where they were, they had no job options.

Despite becoming an important and necessary support space, especially for those in transit, Jirau Village has not received any infrastructure reorganization or improvement, except the construction of a small school, as corroborated by the conclusions of impacts in the Territories of Vainer (2008 ), Silva e Silva (2011), Sassen (2018), Owusu (2017) 
and Moret (2018).

Apparently, the Jirau Village does not seem to have any perspective of work, however people who came mainly from rural areas and who already know the dynamics of a small community like Jirau, that is, it is a space that houses families who are waiting for jobs diversified as those developed on farms, mining, small daily rates on sites and, of course, an expectation of formal work in contractors or companies outsourced by Energia Sustentável do Brasil due to the construction and operation of the Jirau Hydroelectric Plant. The latter is the factor that has influenced the majority of migrants in recent years, according to data collected by our research.

Unexpected and high immigration in a rural community can cause several negative impacts since it does not have adequate infrastructure for sanitation, security, education, among others. Small social problems are beginning to emerge, such as: drug trafficking and use, which has left children, adolescents and young people in a situation of vulnerability. Another situation that was recorded in our interviews was the state of depression that people started to experience due to the lack of perspective of work, income and frustrations of a better life. We also note the absence of public power in social work and the desperation of mothers looking for information or educational and socio-cultural activities that prevent young people and children from becoming addicted to drugs.

It seems that growth, not development, arrived in Jirau Village with the expansion of social problems and is far from becoming a prosperous environment, or rather, according to the speeches of hydroelectric entrepreneurs, at the time of its installation.

\subsection{Penha Village, Madeira River, and surroundings.}

After the construction of the Jirau hydroelectric lake and the floods that occurred in Abunã and Araras, people from these locations moved to Penha Village, as it is the closest safe place (on land) to these two locations. The migration started to be amplified since a strong flood occurred in 2014, caused mainly by the environmental impacts that occurred after the construction of the hydroelectric plant, the same parameters demonstrated by Sassen (2016), where the climatic weather produces opportunities for the economic elite.

Just like the Jirau community, Penha Village has the possibility of growth, because it is next to BR 425, with easy access to the border with Bolivia and BR 364, a highway that accesses Porto Velho (RO) and Rio Branco (AC). In addition, there are many farmers' settlements nearby, what makes it possible to dispose and commercialize production.

Penha Village is a locality isolated from the actions of the government for basic health care, education and other social services. Conflicts are also effected by the high growth in times of flooding and emptying in other periods without, however, having differentiated service from the public authorities, since it is a place of refuge for residents of other communities who also suffer from floods such as Araras and Abunã. There are administrative management conflicts, as Araras belongs to the municipality of Nova Mamoré, while Penha Village and Abunã belong to the municipality of Porto Velho. 
5.3 Analytical perspective of Territory, conflict, and people affected by the construction of HPP in the Amazon.

The conflicts created with the spatial delimitation of the Amazon - as a disruption and disruption between interests in the expansion of capital, are opposed to the lives of citizens in the region.

If Territory is understood as the composition of a complex network of dimensions and relationships that interconnect, forming an invisible web of individual and collective contacts, when these are destroyed, a rupture is created with the symbolic links of social space.

To understand the people affected, in a broad conception, it is necessary to extrapolate the concept of strict pecuniary and material interference that is advocated by the electricity sector, or even by capital, therefore it is connected to material and immaterial influences, as well as (dignified) conditions. of everyday life.

In Jirau Village, there were impacts with the arrival of people who had no option of work, or were in an economically difficult situation, or were still looking for quieter places, as well as because the Territory was close to the enterprise and which allowed easier access to jobs and opportunities offered. Given this, where would former residents and migrants from the last decade of Jirau Village fit in relation to the compensation provided by investors of Energia Sustentável do Brasil?

Penha Village constitutes an escape territory for flooding conditions, which are aggravated by the river dam, becoming a transitory space for these periods, and its dynamics are directly influenced by the operation and operation of the HPP.

Therefore, based on this analytical reflection, it is proposed that in the impacted territory are those that will be affected by Plants, understanding that there is influence and confluence of the networks of life lived, substantiated by the following factors: dwellers);

a) the river and its relation (fishing, fishermen, displacement, prospectors, riverside

b) the connecting roads between the enterprise and the interference space, which delineates and delimits the Territory;

c) housing networks that qualify as a space where workers, or job applicants, are close to the enterprise or to the economic activities resulting from the economic event; and,

d) the escape or refuge spaces to which people place themselves and connect to absorb the impacts caused or even to escape from them.

\section{CONCLUSION}

The only way to consistently overcome conceptions that have the right of the entrepreneur as their core, and not the rights of the affected populations, is to understand the nature of the social process triggered by the hydroelectric enterprise, and of the simultaneously economic, political, cultural and environmental process. It is, in effect, a process of social change that interferes in various dimensions and scales, both spatial and 
temporal. In this process of change, in addition to patrimonial changes (new owners) and morphological changes (new geomorphology, new water regime, etc.), new socioeconomic dynamics are established, new social groups emerge in the region of implantation, new interests and problems appear.

It is suggested that further studies be carried out with a view to expanding the concept of affected, so that the displaced populations will no longer be treated only as an obstacle to (unsustainable) development. It is necessary and urgent that the topic continues to advance so that the social, environmental, cultural, political and economic aspects are recognized by the Judiciary, that the affected populations have a voice and power, are strengthened and such guarantees have their legal effects.

The implantation of UHE destroys constituted social relations and reinstalls others distinct from those marked by harmonious relations with the biome, resulting in a life lived in balance. Using Physics and Thermodynamics, it is understood that abrupt interventions alter energy and, consequently, entropy, quickly producing non-reversibility and placing the system on another entropic level. This distinction between environmental and economic social relations with the environment, therefore at another entropic level, puts society in a worse position than before and which has already been demonstrated in different works by Ribeiro and Moret (2014), Ribeiro, Andrade and Moret (2015), Araujo and Moret (2016). Such a situation violates the current legislation, as it requires that the changes leave people, at least, in the same previous situation.

It is important to highlight the space of interference and which connects with the two localities involved, because this (space of interference) cannot be just the lake or what the entrepreneurs call the affected territory, and which Vainer (2008) calls the Heritage Territory, circumscribed only in the dimensions of the enterprise. The impact happens in the Territory, as defined here in the text, as a result of the influence and the confluence of the networks of lived life, comprising: the river and what relates it, the connecting roads between the enterprise and the interference space, the networks housing, in addition to escape or refuge spaces.

\section{REFERENCES}

ARAUJO, N. C.; MORET, A. S. Direitos Humanos e Hidrelétricas: uma análise dos impactos socioambientais e econômicos gerados em Rondônia. Veredas do Direito. v. 13, p. 167-194, 2016.

BECKER, B. K. Revisão das políticas de ocupação da Amazônia: é possível identificar modelos para projetar cenários? Parcerias Estratégicas. nº 12, set. 2001.

BORTOLETO, E. M. A implantação de grandes hidrelétricas: Desenvolvimento, Discurso e Impactos. Geografares: Vitória. n. 2. Jun, 2001.

BRASIL. MINISTÉRIO DA INFRAESTRUTURA. Plano Diretor de Meio Ambiente do setor elétrico 1991/1993 - PDMA. Rio de Janeiro, 1990. 
CARDONA, O. La necesidad de repensar de manera holística los conceptos de vulnerabilidad y riesgo. Una crítica y una revisión necesaria para la gestión. In: Internacional Work-Conference on Vulnerability in Disaster Theory and Practice. Disaster Studies of Wageningen University y Research Centre, Wageningen. 2001.

CAVAlCANTE, M. M. A; SANTOS, L. J. C. Hydroelectric at the Madeira River: tensions about the territory using and the natural resources in the Amazon. Confins (Paris), p. 1, 2012.

CMB - COMISSÃO MUNDIAL DE BARRAGENS. Barragens e desenvolvimento: Um novo Modelo para tomada de decisões. 2000. Disponível em: https://www2.mppa.mp.br/sistemas/gcsubsites/upload/41/cmb_sumario.pdf Acesso em: 01 fev. 2020.

COMISSÃO MUNDIAL SOBRE O MEIO AMBIENTE E DESENVOLVIMENTO. Nosso futuro Comum. 2 ed., Rio de Janeiro: Fundação Getúlio Vargas, 1991.

DHESCA BRASIL. VIOLAÇÕES DE DIREITOS HUMANOS NAS HIDRELÉTRICAS DO RIO MADEIRA (relatório preliminar). Dhesca: Porto Velho, 2011.

ESCOBAR, A. Sentipensar con la tierra: Nuevas lecturas sobre desarrollo, territorio y diferencia. Medellín: Ediciones UNAULA, 2014.

ESCOBAR, A. Territorios de diferencia: lugar, movimientos, vida, redes. Editorial Universidad del Cauca, 2014.

GARZON, L.F.N. O significado da privatização do rio Madeira: o cercamento das bacias hidrográficas da Amazônia. In: ALMEIDA, Alfredo Wagner Berno de, FARIAS JÚNIOR, Emmanuel de Almeida. (org.) Conflitos sociais no Complexo Madeira. Manaus: PNCSA/UEA Edições, 2009.

GEERTZ, C. A interpretação das culturas. 13. reimpr. Rio de Janeiro: LTC, v. 4, 2008.

JACOBI, P. Movimento ambientalista no Brasil. Representação social e complexidade da articulação de práticas coletivas. In: RIBEIRO, W. (org.) Patrimônio Ambiental EDUSP, 2003.

LIBAULT, A. Os quatro níveis da pesquisa geográfica. Métodos em Questão. Instituto de Geografia (USP), São Paulo, n. 1, 1971, p. 1-14.

LIBISZEWSKI, S. What is an environmental conflict? Zurich: Center for Security Studies, 1992.

MARQUES, W. R. A expansão das fronteiras amazônicas: o legado das Usinas Hidrelétricas (UHEs) Santo Antônio e Jirau no estado de Rondônia (RO). Revista Mutações, Manaus, vol. 08, n. 15, Julho, p. 91-105, 2017.

MORET, A. S.; SILVA, L. L. C. O Rio Madeira, uma Sociedade e a Indústria de Energia: a construção das usinas hidrelétricas e os impactos e intervenções na sociedade. Boletim do Observatório Ambiental Alberto Ribeiro Lamego, Campos dos Goytacazes/RJ, v. 4, n. 2, p. 11-31, jul. / dez. 2010. 
MORET, A. S. Estudo dos impactos sociais, ambientais e econômicos em assentamento de UHE's e a intervenção no circuito inferior da economia. Relatório Científico de Pós-Doc. Instituto de Pesquisa e Planejamento Urbano e Regional- UFRJ. Antônio Calos Brandão- Sup. Rio de Janeiro, 2018.

OWUSU, K. et al.; Resource utilization conflict in downstream non $\square$ resettled communities of the Bui Dam in Ghana. Natural Resources Forum. vol. 41 (4), pp. 234-243, 2017.

RIBEIRO, A. M.; ANDRADE, L. C.; MORET, A. S. Os Estabelecidos e os Outsiders da Amazônia: uma reflexão sociológica acerca de um projeto de reassentamento em Rondônia, Brasil. Territórios e Fronteiras (Online), v. 8, p. 256-274, 2015.

RIBEIRO, A. M.; MORET, A. S. A Construção da hidrelétrica de Santo Antônio e os impactos na sociedade e no ambiente. Interfaces Científicas - Humanas e Sociais. v. 2, p. 81-92, 2014.

SANTOS, M. O dinheiro e o território. GEOgraphia, v. 1, n. 1, p. 7-13, 1999. Disponível em < http://www.geographia.uff.br/index.php/geographia/article/viewFile/2/2> Acesso em: 27 mar. 2019.

SASSEN, S. Expulsões: brutalidade e complexidade na economia global. Rio de Janeiro/São Paulo, Paz e Terra. 2016.

SICILIANO, G. et al.; Hydropower, social priorities and the rural-urban development divide: The case of large dams in Cambodia. Energy Policy. Vol. 86, pp. 273-285, 2015.

SILVA, R. G. S.; SILVA, V. P. Os atingidos por barragens: reflexões e discussões teóricas e os atingidos do assentamento Olhos D'água em Uberlândia-MG. Soc. nat., Uberlândia , v. 23, n. 3, p. 397-407, Dez. 2011.

TAJZIEHCH, S. MONAVARI, S. M. KARBASSI, A. An Effective Participatory-Based Method for Dam Social Impact Assessment. Pol. J. Environ. Stud. v. 21, n. 6, p. 1841-1848, 2012.

VAINER, C. B. Conceito de "atingido": Uma revisão do debate e diretrizes. In: ROTHMAN, Franklin Daniel (ed.). Vidas Alagadas - Conflitos Socioambientais - Licenciamento e Barragens, Viçosa, MG: Ed. UFV. 2008, p. 39-63.

WISNER, B. et. al. At Risk. Natural Hazards, People's Vulnerability and Disasters, Routledge. 2003. 
Artur de Souza Moret

$\checkmark$ amoret@unir.br

ORCiD: https://orcid.org/0000-0000-1737-15486
Submitted on: 27/06/2020

Accepted on: 03/03/2020

2021;24e:01322

\section{Clara Miranda Santos}

$\checkmark$ claramiranda@gmail.com

ORCiD: https://orcid.org/0000-0003-3746-1663

\section{Rafael Ademir Oliveira de Andrade}

$\checkmark$ profrafaelsocio@gmail.com

ORCiD: https://orcid.org/0000-0002-1047-3499

\section{Berenice Perpétua Simão}

$\checkmark$ berenicesimao@yahoo.com.br

ORCiD: https://orcid.org/0000-0002-6938-5346

\section{Jeferson Cardoso da Silva}

$\square$ jeferson.cardoso@ifro.edu.br

ORCiD: https://orcid.org/0000-0003-0597-144X

\section{Clarides Henrich de Barba}

$\checkmark$ clarides@unir.br

ORCiD: https://orcid.org/0000-0002-2950-9033

How to cite: MORET, A.S.; SANTOS, C.M. ANDRADE, R.A.O. SIMÃO, B.P. SILVA, J.C. BARBA, C.H. Expanding the Concept of People Affected by Hpp: Jirau and Penha Village. Ambiente $\&$ Sociedade. São Paulo, v. 24, p. 1-16, 2021. 


\title{
Expandindo a concepção de atingidos por UHE: Assentamentos Vila Jirau e Vila da Penha - Rondônia
}

\author{
Artur de Souza Moret \\ Clara Miranda Santos \\ Rafael Ademir Oliveira de Andrade \\ Berenice Perpétua Simão \\ Jeferson Cardoso da Silva \\ Clarides Henrich de Barba
}

São Paulo. Vol. 24, 2021

Artigo Original
Resumo: Este trabalho tem por objetivo discutir a concepção de atingidos e a da reconfiguração do território e das vidas sociais com a observação e análise de duas comunidades não consideradas afetadas pela UHE Jirau: a do pequeno vilarejo Jirau e Vila da Penha. A pesquisa se caracteriza como teórico-descritiva, a partir das questões relacionadas ao território de ocorrência de impactos da construção e da operação das hidrelétricas, e fora realizado trabalho de campo com observação não participante, os dados foram compilados a partir da percepção dos pesquisadores e possibilitam concluir que os danos da construção da UHE, nessas comunidades colocam-nas em condição de atingidos, o impacto acontece no território como resultado da influência e da confluência das redes de vida vivida, compreendendo o rio e o que o relaciona, as estradas de conexão, as redes de moradia, além dos espaços de fuga ou refúgio.

Palavras-chave: Assentamentos; Atingidos; Hidrelétricas; Complexo do Madeira.

Como citar: MORET, A.S.; SANTOS, C.M. ANDRADE, R.A.O. SIMÃO, B.P. SILVA, J.C. BARBA, C.H. Expandindo a concepção de atingidos por UHE: Assentamentos Vila Jirau e Vila Penha - Rondônia. Ambiente \& Sociedade. São Paulo, v. 24, p. 1-18, 2021. 


\title{
AMPLIACIÓN DEL CONCEPTO DE AFECTADOS POR CH: LOS ASENTAMIENTOS DE VILA JIRAU Y PENHA - RONDÔNIA
}

\author{
Artur de Souza Moret \\ Clara Miranda Santos \\ Rafael Ademir Oliveira de Andrade \\ Berenice Perpétua Simão \\ Jeferson Cardoso da Silva \\ Clarides Henrich de Barba
}

São Paulo. Vol. 24, 2021

Artículo original
Resumen: Este trabajo tiene como objetivo discutir la concepción de los afectados por hidroeléctricas, y la reconfiguración de su territorio y vida social por medio de la observación y análisis de dos comunidades consideradas no afectadas por el Complejo Hidroeléctrico $(\mathrm{CH})$ de Jirau: la pequeña aldea Jirau y Vila da Penha. Esta investigación se define como teórico-descriptiva y se basa en las cuestiones relacionadas al territorio de ocurrencia de impactos de la construcción y operación de planos hidroeléctricos. El trabajo de campo se realizó con observación no participante. Los datos fueron compilados desde la percepción de los investigadores y nos permiten concluir que el daño de la construcción del $\mathrm{CH}$ en estas comunidades de hecho las puso en condición de afectadas. El impacto en el territorio es resultado de la influencia y confluencia de las redes de vida vivida, que comprenden el río y todo lo que se relaciona con él, como los caminos de conexión, las redes de viviendas, bien como los espacios de fuga o refugio.

Palabras-clave: Asentamientos. Afectados. Planos hidroeléctricos. Complejo Madeira.

Como citar: MORET, A.S.; SANTOS, C.M. ANDRADE, R.A.O. SIMÃO, B.P. SILVA, J.C. BARBA, C.H. Expandindo a concepção de atingidos por UHE: Assentamentos Vila Jirau e Vila Penha - Rondônia. Ambiente \& Sociedade. São Paulo, v. 24, p. 1-22, 2021.

DOI:http://dx.doi.org/10.1590/1809-4422asoc20200132r2vu2021L3DAO 